Vol. 24, No. 2, April 2021, hlm. 309-318

p-ISSN: 1410-9344; e-ISSN: 2549-5631

\title{
Perencanaan Keuangan dan Pengelolaan Keuangan Generasi Z di Masa Pandemi COVID-19 melalui Penguatan Literasi Keuangan
}

\author{
Ade Maya Saraswati, Arif Widodo Nugroho
}

Program Studi Akuntansi, Fakultas Ekonomi dan Bisnis, Universitas Muhammadiyah Prof DR.HAMKA

email: ademaya.saraswati@uhamka.ac.id

\section{Article Info}

Submitted: 23 January 2021

Revised: 7 February 2021

Accepted: 6 March 2021

Published: 21 April 2021

Keywords: Financial literacy, Covid-19 Pandemic, Financial Planning, Financial Management
Kata kunci: Literasi keuangan, Pandemi Covid-19, Perencanaan Keuangan, Pengelolaan keuangan

\section{Abstract}

Since the beginning of 2020, particularly since March 2020, Indonesia has been shocked by the emergence of the COVID-19 pandemic. From March to August 2020, the total number of the COVID-19 cases in Indonesia amounted to 165,887 cases, and the death toll reached 7,169 in 34 provinces. The rapid spread and the increasing number of the COVID-19 cases have affected the economic downturn in Indonesia. It was reported that $65 \%$ of Indonesians revealed that their income declined due to the COVID-19 pandemic. Young people are currently demanded to enhance their skills and knowledge in terms of managing their personal finances effectively, amid this pandemic in particular. The studies accomplished in numerous countries have demonstrated that the level of the young people's financial literacy is categorized as a low category. Hence, it is necessary to educate them so that their awareness of the importance of financial planning and financial management can be built. This study utilized particiapatory methods. Education on understanding financial planning and financial management was taught to the students of grade $X$ and grade XI at Madrasah Aliyah Negeri 7 Jakarta through Focus Group Discussion by using Zoom application. The implementation of the education was optimally accomplished, and all parties showed their positive responses. Additionally, this activity was in line with the purpose of this study, namely aiming at increasing awareness of the prominence or importance of either long-term or short-term financial management by considering the economic conditions and practicing financial management in order to attain financial prosperity in the future.

Abstrak
Sejak awal tahun 2020 tepatnya pada bulan Maret, Indonesia
dihebohkan oleh salah satu fenomena yaitu pandemi covid-19.
Sampai dengan bulan Agustus 2020, total kasus di Indonesia 165.887
dengan 7.169 kematian di 34 provinsi. Penyebaran dan peningkatan
jumlah kasus covid-19 terjadi dengan sangat cepat berdampak


pada penurunan perekonomian Indonesia. Tercatat, sebanyak 65\% masyarakat Indonesia mengakui pendapatannya berkurang akibat pandemi Covid-19. Anak muda saat ini dituntut untuk memiliki pengetahuan dan keterampilan untuk mengelola keuangan pribadinya secara efektif terutama di tengah pandemi Covid-19 saat ini. Penelitian dari berbagai belahan dunia membuktikan rendahnya tingkat literasi keuangan khususnya di kalangan kaum muda. Berdasarkan hal tersebut perlu memberikan edukasi untuk menumbuhkan kesadaran akan perencanaan keuangan dan pengelolaan keuangan. Metode kegiatan yang dilakukan adalah metode partisipatif. Edukasi mengenai pemahaman perencanaan dan pengelolaan keuangan diberikan kepada siswa siswi kelas X dan XI Madrasah Aliyah Negeri 7 Jakarta melalui FGD dengan aplikasi Zoom. Pelaksanaan edukasi berjalan dengan baik dan mendapat respon positif dari semua pihak. Kegiatan ini juga dapat memenuhi tujuan awal, yaitu menyadarkan akan pentingnya melakukan perencanaan keuangan baik jangka pendek maupun jangka panjang dengan memperhatikan kejadian dan kondisi ekonomi, serta melakukan pengelolaan keuangan yang terencana dalam rangka mencapai kesejahteraan keuangan di masa depan.

\section{PENDAHULUAN}

Pembatasan Sosial Berskala Besar (PSBB) mulai diterapkan oleh Pemerintah Indonesia sebagai langkah awal merespon pandemi Covid-19. Kegiatan usaha pada berbagai sektor diyakini dapat terhambat dengan kebijakan yang diterapkan oleh pemerintah Indonesia dan jika kebijakan yang telah tertuang dalam Peraturan Pemerintah (PP) Nomor 21 Tahun 2020 terjadi dalam kurun waktu yang relatif lama maka akan menimbulkan kerugian ekonomi (Hadiwardoyo, 2020). Hal yang juga dikhawatirkan dengan diberlakukannya Pembatasan Sosial Berskala Besar (PSBB) adalah kontribusi dari kinerja UMKM dan perekonomian nasional terpengaruh karena aktivitas ekonomi terutama produksi, distribusi, dan penjualan mengalami gangguan.

Terhentinya aktivitas produksi dibanyak negara, turunnya tingkat konsumsi masyarakat, hilangnya kepercayaan masyarakat, dan jatuhya bursa saham yang mengarah pada ketidakpastian adalah ancaman krisis ekonomi besar yang diakibatkan oleh pandemi Covid-19 (OECD, 2020). Penurunan konsumsi dan daya beli masyarakat, penurunan kinerja perusahaan, ancaman pada sektor perbankan dan keuangan, serta eksistensi UMKM adalah bentuk implikasi negatif bagi perekonomian domestik akibat pandemi Covid-19 hal ini menurut kajian yang telah dibuat oleh Kementerian Keuangan.

Pandemi ini menyebabkan berkurangnya tenaga kerja atau bahkan beberapa masyarakat kehilangan pendapatannya sehingga hal ini berpengaruh pada tingkat konsumsi dan daya beli masyarakat terutama mereka yang berada dalam kategori pekerja harian dan pekerja informal, hal ini dilihat dari aspek konsumsi dan daya beli masyarakat. Dalam mengatur pengeluaran keuangannya masyarakat harus berhati-hati dikarenakan belum diketahui pasti kapan pandemi ini berakhir (Pakpahan, 2020).

Pengangguran adalah salah satu dampak pandemi Covid-19 yang dirasakan. Virus ini mewabah dengan sangat cepat di Indonesia dirasakan dari sektor perekonomian. Pengangguran akan meningkat bahkan berpotensi besar meluas karena virus Covid-19 di Indonesia, dapat dilihat dari beberapa perusahaan atau industri lainnya yang harus mem-PHK karyawannya atau di rumahkan dan dihimbau bekerja secara online di rumah masing-masing. Kegiatan membatasi masyarakat untuk beraktivitas di luar adalah salah satu hal yang dapat memicu bertambahnya angka penganguran (Fahri et al., 2020). 
Berdasarkan data Kementerian Ketenagakerjaan tanggal 7 April 2020 tercatat 1.4 juta lebih pekerja di seluruh Indonesia terkena dampak langsung wabah Covid-19 serta perusahaan sektor formal dan perusahaan sektor informal harus merumahkan dan memPHK karyawannya, sebanyak 1.052.216 orang dari perusahaan sektor formal dan 374.851 dari perushaan sektor informal (Humas Biro Kemnaker, 2020). Pandemi Covid-19 menekan pendapatan rumah tangga masyarakat Indonesia dan sebanyak 65\% masyarakat Indonesia mengakui pendapatannya berkurang akibat pandemi (PwC, 2020). Jika penghasilan orang tua menurun tentu akan berdampak pada uang saku yang diterima bagi anaknya.

Keputusan yang diambil oleh kalangan anak muda saat ini sangat berpengaruh pada masa depan mereka dalam jangka waktu yang sangat lama, demi kesejahteraannya anak muda saat ini harus memiliki pengetahuan keuangan dan keterampilan untuk mengelola keuangan pribadinya secara efektif (Putra et al., 2020). Keputusan jangka pendek seperti tabungan dan pinjaman serta keputusan jangka panjang seperti perencanaan pensiun dan perencanaan pendidikan untuk anak adalah hal yang harus dipikirkan matang-matang (Margaretha \& Pambudhi, 2015).

Hasil survei mengatakan bahwa tabungan adalah perencanaan jangka pendek yang masih mendominasi masyarakat Indonesia. Berdasarkan Otoritas Jasa Keuangan (2017) masyarakatyang menyatakan rutin berkomitmen melaksanakan penyusunan anggaran bulanan sebesar 30,7\%, kadang-kadang melakukan penyusunan anggaran sebanyak 55,2\%, dan sebanyak $12,7 \%$ tidak pernah melaksanakan rencana anggaran.

Proses perencanaan keuangan individu adalah bagian penting yang harus dipahami oleh generasi Z, perencanaan keuangan secara individu dapat dilakukan dengan menentukan kondisi keuangan saat ini, Berdasarkan hasil dari Nielsen Millenial Travellers Study menyatakan bahwa anak muda memiliki kecenderungan untuk travelling karena di awal-awal karir generasi muda berkemungkinan melakukan perjalanan lebih banyak karena pendapatan dan keuangan sedang bertumbuh. Serta generasi muda saat ini mengukur kebahagiaan dari pengalaman dan memamerkannya kepada orang sekitar(Putri et al., 2019).

Sehingga perlu membuat tujuan keuangan individu seperti memikirkan kondisi untuk jangka penjang karena generasi Z sekarang tujuan keuangannya hanya untuk saat ini atau jangka pendek, membuat beberapa pilihan untuk memenuhi tujuan keuangan individu, evaluasi setiap pilihan yang telah dibuat, implementasikan program perencanaan keuangan.

Kegiatan mengelola keuangan secara tersusun dan sistematis adalah proses seorang individu dalam memenuhi kebutuhan hidup ini adalah pengertian pengelolaan keuangan yang merupakan bagian dari manajemen keuangan pribadi. Kemampuan untuk membuat suatu pertimbangan dan melakukan investasi dimasa depan adalah bagian dari pengalaman keuangan. Untuk mencapai ketentraman dan kenyamanan dalam hidup maka perlu perencanaan dan pengelolaan investasi yang benar dan baik.

Pemahaman seseorang akan konsep keuangan dan kemampuan dalam mengatur keuangan secara pribadi berdasarkan pengambilan keputusan jangka pendek yang tepat dijadikan sebagai tolak ukur tingkat pemahaman terhadap literasi keuangan Remund (2010). Penelitian dari berbagai belahan dunia membuktikan rendahnya tingkat literasi keuangan khususnya pada kaum muda (Agarwalla et al., 2015; Allgood \& Walstad, 2013; Lusardi et al., 2010; Lusardi \& Mitchell, 2011; Van Rooij et al., 2011) hal menjadi sangat krusial jika individu tidak memiliki kemampuan dalam mengamankan kesejahteraan finansialnya. Kaum muda saat ini tumbuh dalam masyarakat yang lanskap keuangannya kompleks dan tanggung jawab keuangan warganya sangat besar.

Keamanan keuangan dan standar hidup seseorang dipengaruhi oleh pilihannya yang berubah-ubah dari hari ke hari, mengelola keuangan secara pribadi merupakan salah satu kompetensi yang paling mendasar yang dibutuhkan. Kesalahan dalam mengelola keuangan dapat terjadi karena mengalami kesulitan keuangan (Yushita, 2017). Literasi keuangan sangat berhubungan erat dengan pengelolaan keuangan. Seseorang yang memiliki tingkat penghasilan yang tinggi tetapi tidak 
mempunyai kemampuan pengelolaan keuangan yang tepat maka keamanan finansial pasti akan sulit tercapai, maka dari itu perlu pengelolaan keuangan yang tepat dan ditunjang dengan literasi keuangan yang baik sehingga diharapkan meningkatnya taraf hidup masyarakat.

Agar dapatterhindar dari masalah keuangan penting untuk mengetahui tentang literasi keuangan, karena literasi keuangan merupakan kebutuhan dasar. Generasi dapat menikmati hidup dengan sumber daya keuangan yang dimiliki karena memiliki pemahaman literasi keuangan sangat baik. Mencapai kesejahteraan adalah tujuan dari pengetahuan tentang keuangan ini adalah pengertian dari literasi keuangan. Kemampuan dalam merencanakan masa depan, kemampuan mencakup untuk membedakan pilihan keuangan, membahas mengenai uang dan masalah keuangan, dan memiliki kecakapan dalam pengambilan keputusan keuangan sehari-hari dalam berbagai peristiwa kehidupan, termasuk peristiwa di ekonomi secara umum itu semua adalah definisi dari literasi keuangan

Menurut (Chen \& Volpe, 2016) terdapat empat dimensi literasi keuangan, yaitu: (1) Kemampuan mengatur pendapatan dan pengeluaran serta paham konsep dasar keuangan hal itu berarti sudah memiliki pengetahuan tentang keuangan mencakup pengetahuan keuangan pribadi; (2) Menyimpan uang di bank dan dalam penarikan uang tersebut dapat dilakukan dengan syarat tertentu merupakan definisi tabungan (Otoritas Jasa Keuangan, 2016); (3) Perjanjian antara dua pihak, yaitu perusahaan asuransi dan pemegang polis, di mana pemegang polis sebagai penerima premi dari perusahaan asuransi adalah pengertian dari asuransi (Undang-undang No. 40 Tahun 2014); dan (4) Untuk dapat menuai keuntungan di masa depan penting untuk memiliki komitmen terhadap pengunaan uang atau sumber daya lainnya merupakan definisi dari investasi (Pawitri, 2017)

Sekolah Madrasah Aliyah Negeri 7 berlokasi di wilayah Jakarta Selatan. Gambar 1 menunjukkan berdasarkan hasil survei yang dilakukan pada siswa-siswi Madrasah Aliyah Negeri 7 Jakarta mengungkapkan bahwa 61\% penghasilan orang tua menurun selama pandemi Covid-19, 87\% siswa mengalami pengurangan uang saku, 70\% siswa mengurangi alokasi untuk menabung, namun 68\% siswa tidak mengurangi konsumsinya selama pandemi Covid-19.

Siswa-siswi Madrasah Aliyah Negeri 7 Jakarta termasuk generasi $\mathrm{Z}$ dengan tahun kelahiran 2002-2004. Generasi yang lahir di tahun 1995-2010 adalah generasi Z (Bencsik et

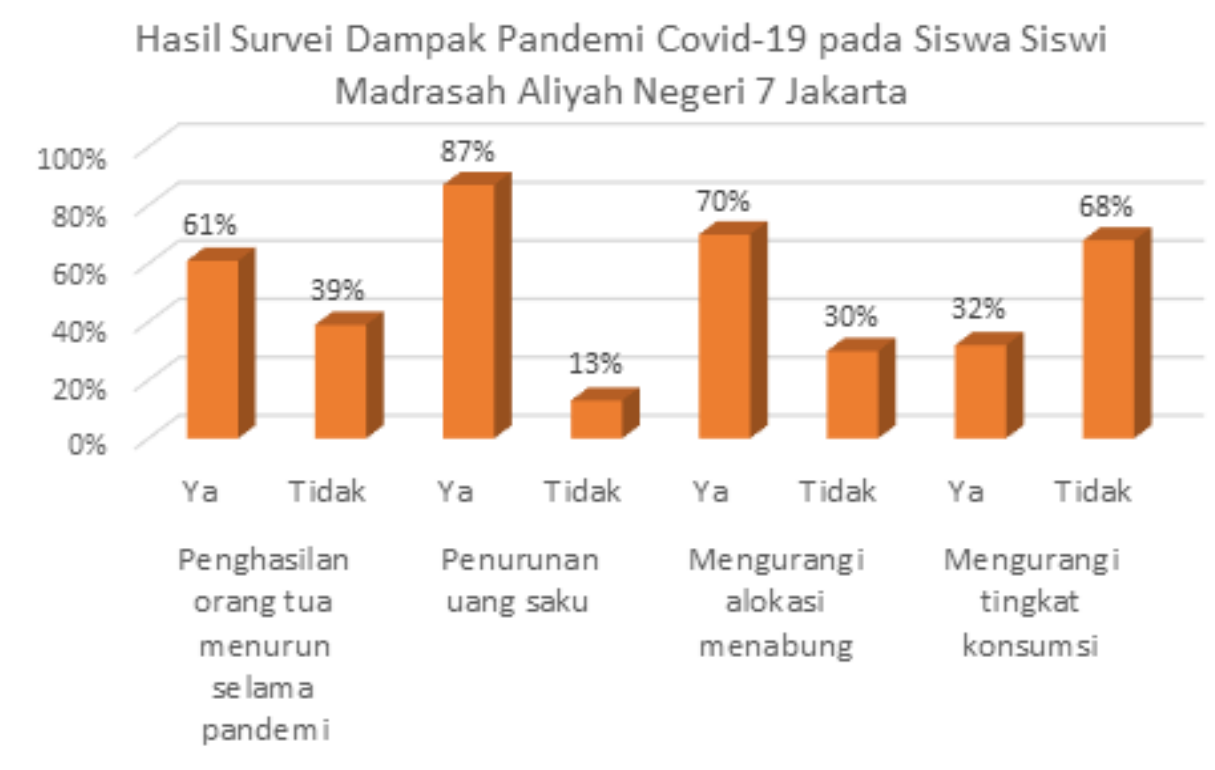

Gambar 1. Hasil Survei pada Siswa Siswi Madrasah Aliyah Negeri 7 Jakarta 
al., 2016). Menurut (Ali et al., 2017) generasi $\mathrm{Z}$ memahami pentingnya menabung, tetapi hanya sedikit pendapatan yang disisihkan sebagai tabungangan. Hal ini disebabkan generasi $\mathrm{Z}$ mengikuti gaya hidup yang berubah-ubah, mengikuti pandangan trend fear of missing out (ketakutan tertinggal tren yang tengah berlangsung di komunitas), dan you only live once (menikmati hidup saat ini tanpa perlu memikirkan masa depan) dan kurangnya pengetahuan pengelolaan keuangan dapat menjadi tantangan tersendiri bagi generasi $\mathrm{Z}$ untuk mengatur keuangan.

Sekumpulan kebiasaan, gaya hidup, pandangan dan pola-pola respon terhadap hidup, perlengkapan untuk hidup adalah pengertian dari gaya hidup. Cara bagaimana seseorang menggunakan uangnya, bagaimana seseorang hidup, bagaimana mereka mengalokasikan waktunya, dan sebagainya juga pengertian dari gaya hidup (Putri et al., 2019).

Hasil peninjauan awal (overview) menunjukkan bahwa siswa-siswi Madrasah Aliyah Negeri 7 Jakarta sudah memiliki pengetahuan yang cukup baik akan produk keuangan. Akan tetapi, untuk kepemilikan produk keuangan baru hanya sebatas pada tabungan saja, selain itu juga masih minimnya akan kesadaran dalam menyusun perencanaan keuangan dengan benar dan masih minimnya pengetahuan akan pengelolaan keuangan. Meningkatnya kompleksitas dan layanan keuangan dan ketersediaan berbagai macam produk membuat kalangan anak muda menemukan kesulitan dalam mengelola keuangan (Garg \& Singh, 2018). Oleh karena itu, diperlukan peningkatan literasi keuangan agar dapat menumbuhkan kesadaran akan perencanaan keuangan dan pengelolaan keuangan.

Pengambilan keputusan dalam pembelian suatu barang adalah hal yang penting untuk dipikirkan, dengan pengetahuan tentang literasi keuangan seseorang dapat memutuskan dengan tepat, pengelolaan keuangan tidak dapat berjalan dengan baik jika pengetahuan mengenai literasi keuangan seseorang masih rendah. masyarakat dengan latar belakang pengetahuan keuangan yang baik akan sadar dan lebih mementingkan proritas. Masyarakat dengan Pendidikan tinggi dan kondisi finansial mapan biasanya memiliki pengetahuan dan kesadaran dalam pengelolaan keuangan yang baik namun tidak menutup kemungkinan mereka membelanjakan uangnya secara berlebihan tanpa adanya perhitungan dengan baik karena mereka terdesak dengan gaya hidup yang ada pada lingkungannya.

Berdasarkan Survei Nasional Literasi Keuangan tahun 2013 yang dilakukan oleh OJK, indeks literasi keuangan masyarakat Indonesia hanya sekitar $21,8 \%$ yang berarti dari setiap 100 penduduk hanya sekitar 22 orang yang termasuk kategori well literate, sufficient literate sebanyak $75,69 \%$ berarti jika ada 100 penduduk ada sekitar 76 orang dalam kategori ini, dan termasuk kategori less literate sebanyak $2,06 \%$ dan not literate 0,41\% (Otoritas Jasa Keuangan, 2017). Hal tersebut menunjukkan bahwa masyarakat Indonesia belum sepenuhnya memiliki pengetahuan yang cukup mengenai bagaimana mengoptimalkan uang untuk kegiatan yang produktif serta belum memahami dengan baik berbagai produk dan layanan jasa keuangan yang ditawarkan oleh Lembaga jasa keuangan formal.

Literasi dan inklusi keuangan adalah program dari pemerintah dan Otoritas Jasa Keuangan dalam upaya meningkatkan literasi keuangan (Otoritas Jasa Keuangan, 2017). Secara khusus, Penguatan literasi keuangan pada generasi Z di Madrasah Aliyah Negeri 7 Jakarta diharapkan dapat meningkatan kemampuan untuk melakukan penyusunan perencanaan dan pengelolaan keuangan, dengan pengetahuan tersebut pengelolaan keuangan dapat dijalankan sesuai perencanaan keuangan yang telah dibuat di masa pandemi Covid-19.

\section{METODE}

Pelaksanaan pengabdian kepada masyarakat ini terdiri dari beberapa tahapan dengan metode kegiatan yang dilakukan adalah metode partisipatif yang berarti pada kegiatan pengabdian masyarakat peran aktif dari mitra yaitu Madrasah Aliyah Negeri 7 sangat dibutuhkan, secara menyeluruh untuk menyelesaikan permasalahan pada mitra dan terlaksananya kegiatan pengabdian kepada masyarakat ini dengan baik kegiatan akan dilaksanakan dengan tahapan diantaranya: 1) analisis kebutuhan dan permasalahan, 
2) Perencanaan pelaksanaan edukasi, 3) Pelaksanaan edukasi, dan 4) Evaluasi kegiatan.

Tahap analisis kebutuhan dan situasi dilakukan bersama dengan Kepala Sekolah Madrasah Aliyah Negeri 7 Jakarta. Pada tahapan ini, semua kebutuhan dan permasalahan yang diusulkan oleh mitra untuk dibuat perancangan kegiatannya, berdasarkan hasil diskusi sasaran pemberian materi merupakan siswa-siswi kelas X dan kelas XI. Setelah melakukan analisis kebutuhan dan permasalahan dilakukan koordinasi antara tim pengusul PKM dengan mitra sebagai bentuk persiapan pelaksanaan program kegiatan kemitraan, dilakukan sosialisasi program pelaksanaan, agar seluruh siswa-siswi kelas X dan kelas XI dapat hadir. Pada tahap pelaksanaan edukasi disepakati pelaksanaan kegiatan dilaksanakan pada hari Rabu tanggal 16 Desember 2020 pukul 08:0009:30 dilakukan secara online menggunakan aplikasi Zoom, dengan satu orang narasumber, satu orang moderator yang merupakan dosen dan satu orang mahasiswa sebagai host. Pelaksanaan dilakukan dengan penyampian materi oleh narasumber dan dilanjutkan dengan sesi tanya jawab dan diskusi. Monitoring dan evaluasi (monev), tim pelaksana melakukan monev apakah PKM yang telah dilakukan itu berhasil dilaksanakan oleh siswa-siswi kelas X dan XI MAN 7 Jakarta secara berkelanjutan atau tidak. Tingkat keberhasilan pelatihan ini dilakukan melalui pertanyaan-pertanyaan ada dalam kuesioner untuk melihat apakah terjadi peningkatan atas pemahaman dan kesadaran akan pentingnya mengelola keuangan dan merencanakan keuangan.

\section{HASIL DAN PEMBAHASAN}

Penentuan materi literasi keuangan dilakukan melalui diskusi dengan Kepala Sekolah. Hal tersebut dilakukan supaya kegiatan edukasi yang diberikan sesuai dengan kondisi dan kebutuhan siswa-siswi sebagai genarasi Z. Berdasarkan hasil diskusi dapat disimpulkan bahwa kebutuhan siswa-siswi sebagai generasi Z yang sedang mengalami masa pandemi Covid-19 adalah pembahasan terkait dengan perencanaan dan pengelolaan keuangan di masa pandemi Covid-19.

Pelaksanaan webinar dilakukan melalui
Focus Gorup Discussion yang dilaksanakan dengan aplikasi Zoom pada hari Rabu tanggal 16 Desember 2020 pukul 08.00-09.30 WIB. Kegiatan tersebut dihadiri oleh Wakil Kepala Sekolah, perwakilan guru ekonomi, perwakilan guru bimbingan konseling, dan 220 siswa-siswi kelas X dan kelas XI MAN 7 Jakarta.

FGD diawali dengan sambutan sekaligus pembukaan oleh wakil kepala sekolah, sambutan oleh guru ekonomi, dan pemaparan materi oleh narasumber selama 45 menit. Selama sesi pemaparan materi, peserta diskusi menyimak materi yang disampaikan, materi tersebut merupakan materi yang disusun berdasarkan teori-teori ilmiah dari sumber-sumber primer buku. Oleh karena itu, penyampaian materi dibuat lebih sederhana dan menyenangkan agar dapat diterima dan dipahami oleh siswa-siswi.

Materi awal yang diberikan adalah karakteristik generasi Z, sindrom generasi Z, dan perencanaan keuangan dari perspektif Al-Quran. Perintah untuk melaksanakan perencanaan keuangan yaitu QS. Al-Hasyr:18 "Wahai orangorang yang beriman bertakwalah kepada Allah dan hendaklah setiap orang memperhatikan apa yang telah diperbuatnya untuk hari esok (akhirat), dan bertakwalah kepada Allah. Sungguh Allah Mahateliti terhadap apa yang kamu kerjakan (Kamaluddin, 2014), dan pada surat QS. An-Nisa: 9 "Dan hendaklah takut kepada Allah orang-orang yang seandainya meninggalkan di belakang mereka anak-anak yang lemah yang mereka khawatir terhadap (kesejahteraan) mereka. Oleh sebab itu hendaklah mereka bertakwa kepada Allah dan hendaklah mereka mengucapkan perkataan yang benar"(Noviandy, 2017).

Materi berikutnya adalah penjelasan cash flow management yaitu hubungan waktu antara penghasilan yang didapat, pengeluaran, dan yang dapat ditabung, pada cash flow management usahakan pengeluaran tidak lebih besar dari pemasukan (Marrocco, 2020). Metode-metode yang dapat dilaksanakan dalam perencanaan dan pengelolaan keuangan yaitu metode ZAPFIN yaitu seperti penghasilan yang dimiliki digunakan untuk menabung pembelian besar sebesar 5\%, premi asuransi 5\%, dana darurat $5 \%$, zakat, sedekah dan sosial $5 \%$, gaya hidup dan hiburan $10 \%$, investasi masa depan $10 \%$, 
dan persenan paling besar digunakan untuk biaya hidup bulanan dan cicilan sebesar $60 \%$ (Ghozie, 2013).

Salman Al-Farisi memiliki gambaran mengenai mengatur keuangan yaitu $1 / 3$ sedekah, 1/3 keperluan keluarga, dan 1/3 investasi. Walau sebenarnya gambaran Salman Al-Farisi mengenai mengatur keuangan bertolak belakang dengan teori ekonomi profesional di mana semakin besar pendapatan semakin besar konsumsi tetapi menurut Salman Al-Farisi semakin besar sedekah (Parisi, 2017).

Individu yang memiliki tujuan keuangan maka akan memiliki sikap keuangan yang bijak. Untuk merencanakan dan mengelola keuangan jangka pendek maupun jangka panjang individu harus memiliki tujuan keuangan. Mencapai tujuan keuangan yang cerdas ada beberapa hal yang dapat dilakukan yaitu (specific) mengetahui barang atau kebutuhan apa yang akan dibeli dengan uang yang dimiliki, (Mesureable) jumlah dana yang dibutuhkan untuk dapat membeli kebutuhan, (Attainable) membuat rencana langkah demi langkah untuk dapat mencapai tujuan dengan tepat, (Realistic) dalam mencapai tujuan tersebut perlu dipikirkan konsekuensi yang mungkin terjadi dan sebisa mungkin meminimalisir risiko yang mungkin terjadi dalam mencapai tujuan tersebut, (Time Bound) waktu yang dibutuhkan untuk mencapai tujuan tersebut (Robins, 2014).
Tahap selanjutnya adalah tanya jawab dan diskusi, dalam tahap ini ada beberapa pertanyaan mendasar tentang materi yang disampaikan. Terdapat 15 (lima belas) pertanyaan yang diajukan oleh siswa-siswi terkait dengan perencanaan keuangan maupun pengelolaan keuangan, hal ini dapat disimpulkan bahwa siswa-siswi menerima dengan baik materi yang disampaikan.

Berdasarkan hasil survei yang telah dilakukan kepada siswa siswi Madrasah Aliyah Negeri 7 Jakarta dapat dilihat pada Gambar 2 dari pengelolaan keuangan sebelum kegiatan webinar, sebesar 58\% siswa dan siswi belum memiliki pengetahuan dan pemahaman konsep pengelolaan keuangan yang benar dan tepat dan sebesar 42\% sudah memahami konsep keuangan yang benar dan tepat. Setelah dilaksanakan kegiatan webinar sebesar 81\% peserta sudah memahami dan mengetahui konsep pengelolaan keuangan yang tepat dan 19\% masih belum memahami pengelolaan keuangan yang tepat. Terjadi peningkatan pemahaman dan pengetahuan mengenai pengelolaan keuangan sebesar 39\% terlihat pada grafik yang ditunjukkan pada Gambar 2, hal ini berarti kegiatan webinar yang telah dilaksanakan sangat membantu siswa dan siswi dalam memiliki pengetahuan dan pemahaman pengelolaan keuangan.

\section{Hasil Survei Pengelolaan Keuangan Sebelum dan Setelah}

\section{Webinar}

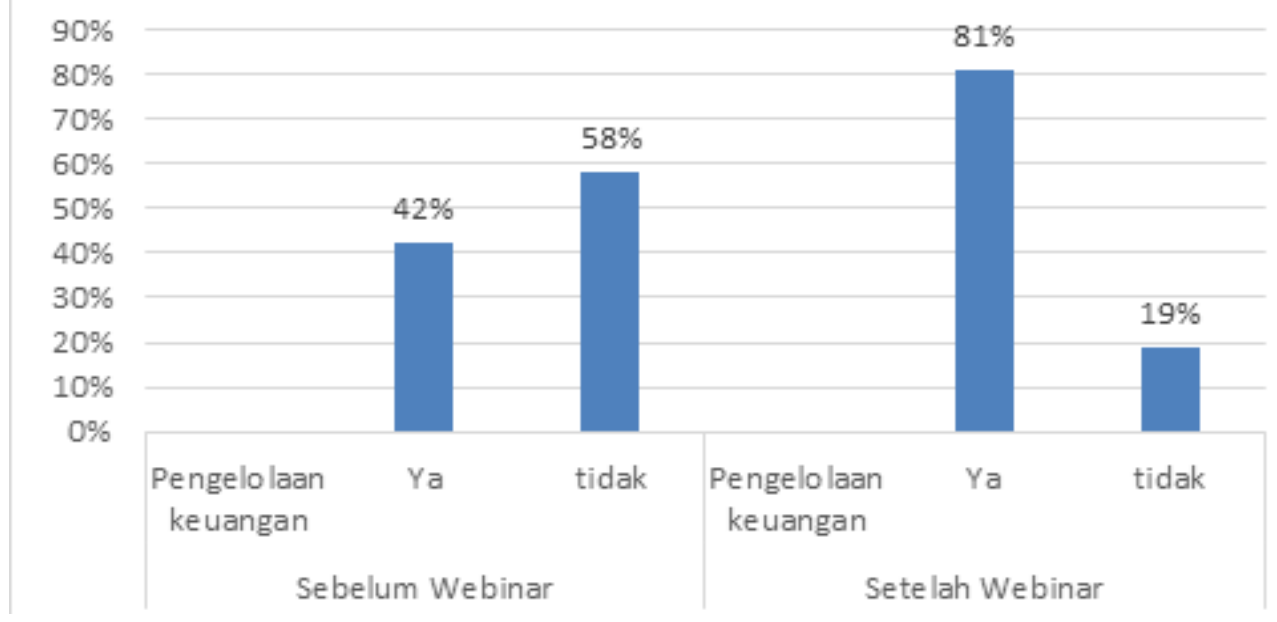

Gambar 2. Hasil Survei Pengelolaan Keuangan 


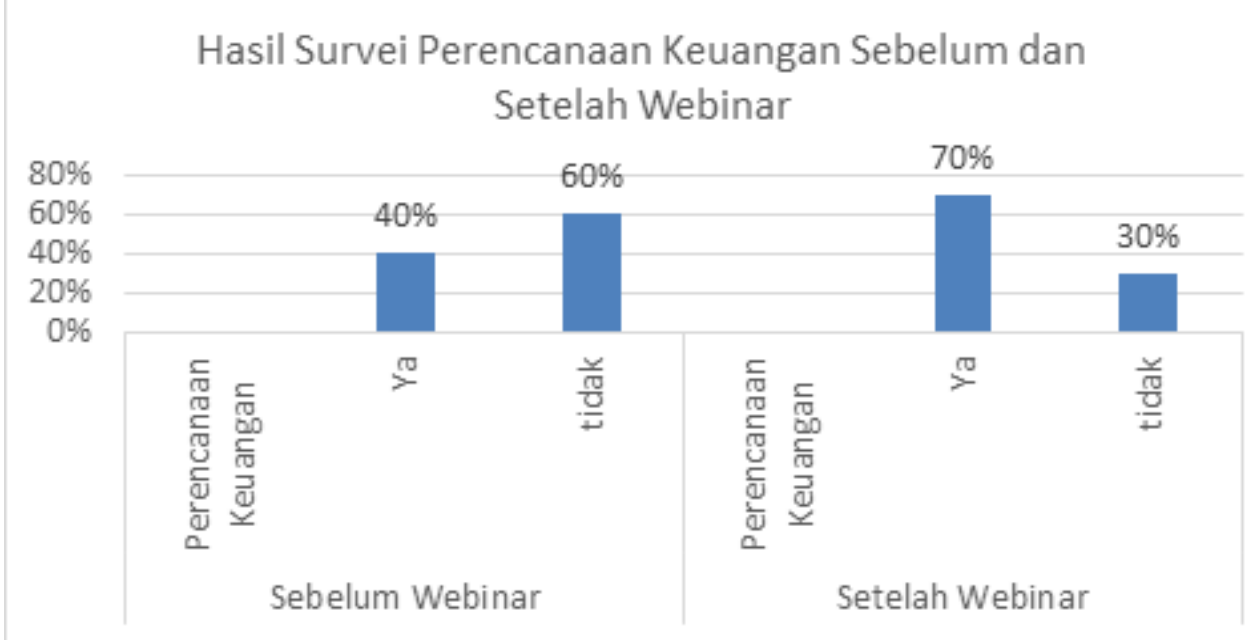

Gambar 3. Hasil Survei Perencanaan Keuangan

Berdasarkan hasil survei perencanaan keuangan yang telah dilakukan kepada siswa siswi Madrasah Aliyah Negeri 7 Jakarta dapat dilihat pada Gambar 3 dari perencanaan keuangan sebelum kegiatan webinar, sebesar $60 \%$ siswa dan siswi belum memiliki pengetahuan perencanaan keuangan seperti mengalokasikan nya untuk menabung dan melakukan perencanaan keuangan jangka pendek maupun jangka panjang dan sebesar $40 \%$ sudah memahami konsep perencanaan keuangan yang benar dan tepat. Setelah dilaksanakan kegiatan webinar sebesar 70\% peserta sudah memahami dan mengetahui perencanaan keuangan jangka pendek maupun jangka Panjang dan dapat merencanakan keuangan dengan baik. 30\% siswa dan siswi masih belum memahami perencanaan keuangan yang tepat. Terjadi peningkatan pemahaman dan pengetahuan mengenai perencanaan keuangan sebesar $30 \%$ dari $40 \%$ menjadi $70 \%$ dapat dilihat pada Gambar 3 di atas, hal

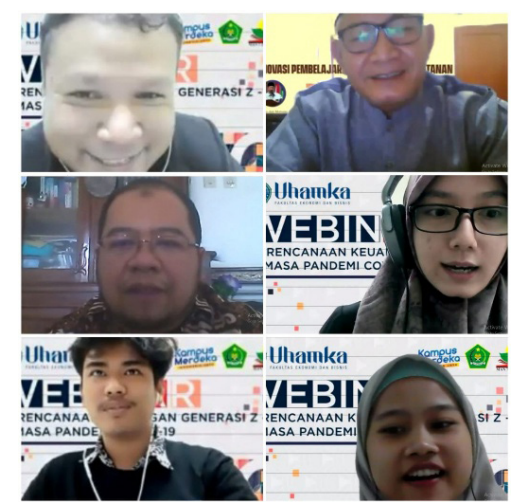

Gambar 4. Webinar Virtual ini menunjukkan kegiatan webinar yang telah dilaksanakan sangat membantu siswa dan siswi dalam memiliki pengetahuan dan pemahaman perencanaan keuangan.

Peran aktif akademisi untuk terjun langsung memberikan edukasi melalui webinar kepada generasi $\mathrm{Z}$ merupakan salah satu upaya paling efektif dalam penguatan literasi keuangan. baik pendidik seperti dosen maupun peserta yaitu siswa-siswi MAN 7 Jakarta. Transfer ilmu pengetahuan diberikan oleh pendidik kepada siswa-siswi kelas X dan XI MAN 7 sebagai peserta didik, sedangkan peserta didik dapat melanjutkan informasi yang diperoleh di dunia pendidikan kepada keluarga atau orang-orang di sekitarnya.

Pelaksanaan edukasi berjalan dengan sangat baik, mendapat respon positif, baik dari siswa-siswi, guru, dan kepala sekolah. Selain itu, kegiatan ini juga dapat memenuhi tujuan dan target awal kegiatan, yaitu menyadarkan akan

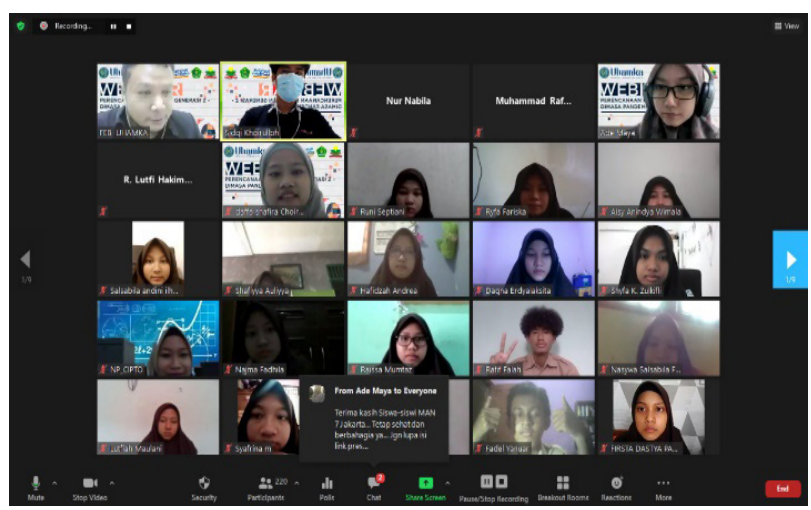

Gambar 5. Pelaksanaan Webinar 
pentingnya melakukan perencanaan keuangan baik jangka pendek maupun jangka panjang dengan selalu memperhatikan kejadian dan kondisi ekonomi, serta melakukan pengelolaan keuangan yang terencana dalam rangkai mencapai kesejahteraan keuangan di masa depan.

Kegiatan pengabdian ini diberitakan pada media elektronik Koranmu pada hari Jumat 18 Desember 2020. Alamat elektronik dapat diakses secara online melalui link https://www. koranmu.com/2020/12/webinar-feb-uhamkaperencanaan-keuangan.html.

\section{SIMPULAN}

Pelaksanaan edukasi melalui FGD untuk penguatan literasi keuangan secara kualitatif dapat dinilai telah berjalan dengan sangat baik dan sesuai target capaian. Hal ini ditunjukkan berdasarkan jawaban dari kuesioner siswa-siswi mengalami peningkatan dalam hal pengelolaan keuangan dan perencanaan keuangan.

Generasi Z diharapkan sudah mampu mengelola keuangan dan mengatasi berbagai masalah keuangan yang dihadapi dengan pengetahuan, keterampilan, keyakinan serta sikap yang telah dimiliki, serta dapat merencanakan keuangan baik jangka pendek maupun jangka panjang, selain itu mengimplementasikan ilmu yang sudah dimiliki tersebut dalam kehidupan sehari - hari.

Kontribusi dan kolaborasi dari berbagai pemangku kepentingan dapat memaksimalkan pencapaian target indeks literasi dan inklusi keuangan yang setinggi-tingginya, tetapi selain pemangku kepentingan komitmen yang tinggi serta kesamaan pandang dari semua pihak juga dapat mewujudkan berbagai macam kegaiatan literasi dan inklusi.

\section{PERSANTUNAN}

Ucapan terima kasih di sampaikan kepada Kepala Sekolah Madrasah Aliyah Negeri 7 Jakarta, Wakil Kepala Sekolah, perwakilan guru, siswa-siswi kelas X dan kelas XI Madrasah Aliyah Negeri 7 Jakarta yang telah mengikuti webinar, mahasiswa Fakultas Ekonomi dan Bisnis, Dosen Universitas Muhammadiyah Prof DR. HAMKA, serta semua pihak yang telah mendukung dan membantu pelaksanaan kegiatan pengabdian kepada masyarakat ini.

\section{REFERENSI}

Agarwalla, S. K., Barua, S. K., Jacob, J., \& Varma, J. R. (2015). Financial Literacy among Working Young in Urban India. World Development, 67(2013), 101-109. https://doi.org/10.1016/j. worlddev.2014.10.004

Ali, H., Purwandi, L., Nugroho, H., Ekoputri, A. W., \& Halim, T. (2017). The Urban Middle-Class Indonesia: Financial and Online Behavior. Alvara Research Center.

Allgood, S., \& Walstad, W. (2013). Financial Literacy and Credit Card Behaviors : A Cross-Sectional Analysis by Age Financial Literacy and Credit Card Behaviors: A Cross-Sectional Analysis. Numeracy, 6(2), 1-26.

Bencsik, A., Juhász, T., \& Horváth-Csikós, G. (2016). Y and Z Generations at Workplaces. Journal of Competitiveness, 6(3), 90-106. https://doi.org/10.7441/joc.2016.03.06

Chen, H., \& Volpe, R. (2016). An Analysis of Personal Financial Literacy Among College Students. Zhongguo Jiguang/Chinese Journal of Lasers, 43(8), 107-128. https://doi.org/10.3788/ CJL201643.0811001

Fahri, Jalil, A., \& Kasnelly, S. (2020). Meningkatnya Angka Pengangguran Ditengah Pandemi (COVID-19). Al Mizan:Jurnal Ekonomi Syariah, 2(2), 45-60.

Garg, N., \& Singh, S. (2018). Financial Literacy among Youth. International Journal of Social Economics, 45(1), 173-186. https://doi.org/10.1108/IJSE-11-2016-0303 
Saraswati dan Nugroho - Perencanaan Keuangan dan Pengelolaan Keuangan ...

Ghozie, P. H. (2013). Make it Happen! PT.Gramedia Pustaka Utama.

Hadiwardoyo, W. (2020). Kerugian Ekonomi Nasional Akibat Pandemi Covid-19. Baskara Journal of Business and Enterpreneurship, 2(2), 83-92. https://doi.org/10.24853/baskara.2.2.83-92

Humas Biro Kemnaker. (2020). Menaker Ida Fauziyah Minta Pengusaha Jadikan PHK sebagai Langkah Terakhir. Kementrian Ketenagakerjaan.

Kamaluddin. (2014). Peringatan Bagi Orang Yang Beriman ( Tafsir Surah Al-Hasr Ayat 18-21). 1.

Lusardi, A., \& Mitchell, O. S. (2011). Financial Literacy and Retirement Planning in the United States. In NBER Working Paper No. 17108. https://doi.org/10.1017/CB09781107415324.004

Lusardi, A., Mitchell, O. S., \& Curto, V. (2010). The Journal of Consumer Affairs. The Journal of Consumer Affairs, 44(2), 358-380.

Margaretha, F., \& Pambudhi, R. A. (2015). Tingkat Literasi Keuangan pada Mahasiswa S-1. Jurnal Manajemen Dan Kewirausahaan, 17(1), 76-85. https://doi.org/10.9744/jmk.17.1.76

Marrocco, J. (2020). Create a Personal Cash Flow Management System That Works For You. Thinking Big Financial.

Noviandy. (2017). Kesejahteraan dalam Perpektif Islam: Analisa Ekonomi Kerakyatan. III(01), 70-80.

OECD. (2020). Covid-19: SME Policy Responses. In Oecd 2020 (Issue March).

Otoritas Jasa Keuangan. (2017). Strategi Nasional Literasi Keuangan Indonesia (Revisit 2017). In Otoritas Jasa Keuangan.

Pakpahan, A. (2020). Covid-19 dan Implikasi Bagi Usaha Mikro, Kecil, dan Menengah. Jurnal Ilmiah Hubungan Internasional, O(0), 59-64. https://doi.org/10.26593/jihi.v0i0.3870.59-64

Parisi, S. Al. (2017). Tingkat Efisiensi dan Produktivitas Lembaga Zakat di Indonesia. Esensi, 7(1). https://doi.org/10.15408/ess.v7i1.3687

Pawitri, R. N. (2017). Kedudukan dan Perlindungan Hukum Pemegang Polis pada Perusahaan Asuransi Yang Pailit Berdasarkan Undang-Undang Nomor 40 Tahun 2014 Tentang Perasuransian. Wacana Hukum, XXIII(April), 40-49.

Putra, L. V., Khoiriyah, I. S. A., \& Sacipto, R. (2020). Penerapan Financial Literacy dalam Pengelolaan Keuangan Siswa. Jurnal Karya Abadi, 4(1), 132-135.

Putri, N. A., Lestari, D., Bisnis, F., \& Teknologi, I. (2019). Pengaruh Gaya Hidup dan Literasi Keuangan Muda di Jakarta. Akurasi: Jurnal Riset Akuntansi Dan Keuangan, 1(1), 31-42.

PwC. (2020). Survei PwC: Pandemi Mengubah Perilaku Konsumen. PwC.

Remund, D. L. (2010). Financial Literacy Explicated: The Case for a Clearer Definition in an Increasingly Complex Economy. The Journal of Consumer Affairs, 44(2), 276-295.

Robins, E. M. (2014). An Instructional Approach to Writing SMART Goals. 19th Annual Technology, Colleges, and Community Worldwide Online Conference.

Van Rooij, M. C. J., Lusardi, A., \& Alessie, R. J. M. (2011). Financial literacy and retirement planning in the Netherlands. Journal of Economic Psychology, 32(4), 593-608. https://doi.org/10.1016/j. joep.2011.02.004

Yushita, A. (2017). Pentingnya Literasi Keuangan Bagi Pengelolaan Keuangan Pribadi. Nominal: Barometer Riset Akuntansi Dan Manajemen, 6(1), 11-26. 